This pre-print manuscript Degradation of two soluble proteins - casein and egg protein by a macro-in vitro method was subsequently accepted by Journal of Animal Physiology and Animal Nutrition.

This version of the manuscript has not been peer-reviewed.

Published with permission from Blackwell Verlag $\mathrm{GmbH}$.

Statement from the publisher: ""This is the pre-peer reviewed version of the following article: [Udén, P. (2012) Degradation of two soluble proteins - casein and egg protein by a macro-in-vitro method. Journal of animal physiology and nutrition, vol.97 (4), pp. 656-665.], which has been published in final form at [ http://dx.doi.org/10.1111/j.1439-0396.2012.01306.x ]."

Epsilon Open Archive http://epsilon.slu.se 


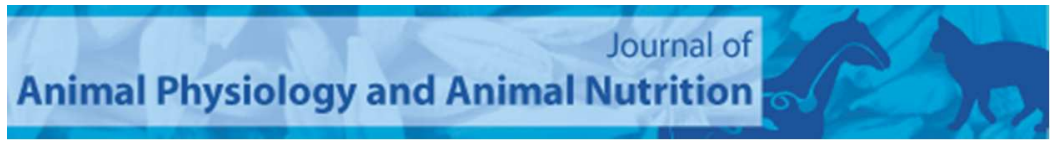

\section{Degradation of two soluble proteins - casein and egg protein by a macro-in vitro method}

\begin{tabular}{|r|l|}
\hline Journal: & Journal of Animal Physiology and Animal Nutrition \\
\hline Manuscript ID: & JAPAN-Nov-11-431.R2 \\
\hline Manuscript Type: & Original Article \\
\hline Date Submitted by the Author: & n/a \\
\hline Complete List of Authors: & $\begin{array}{l}\text { Udén, Peter; Swedish University of Agricultural Sciences, Kungsängen } \\
\text { Research Centre }\end{array}$ \\
\hline Subject Area: & Feed, Nutrition, Ruminants \\
\hline \multicolumn{2}{|l}{} \\
\hline
\end{tabular}

SCHOLARONE ${ }^{\text {IM }}$

Manuscripts 
1

2

3

4

5

6

7

8

9

10

11

Degradation of two soluble proteins - casein and egg protein by a macro-in vitro method

P. Udén

Department of Animal Nutrition \& Management, Kungsängen Research Centre, Swedish University of Agricultural Sciences, S-753 23 Uppsala, Sweden

\section{SUMMARY}

Degradation of casein and egg protein were studied with whole rumen contents (RC) in a macro-in vitro system to elucidate previous findings of initial rapid disappearance of soluble proteins in vitro. Five to $7.5 \mathrm{~kg}$ of rumen contents from a dry and/or a lactating cow were incubated with buffer and casein or egg protein for $180 \mathrm{~min}$ with frequent sampling.

Degradation was measured as loss of trichloroacetic acid precipitable N (TCA-N) from the inocula. Normal $\left(39^{\circ} \mathrm{C}\right)$ and low $\left(2^{\circ} \mathrm{C}\right)$ temperature incubations were examined in Exp. 1, using $1 \mathrm{~g}$ of TCA-N from casein. Four levels of casein (0-12 g TCA-N) in Exp. 2 and four levels of egg albumin (0-24 g TCA-N) in Exp. 3, were fermented at $39^{\circ} \mathrm{C}$. Initial recovery of casein TCA-N was $106 \%$ at $2^{\circ} \mathrm{C}$ and $56 \%$ at $39^{\circ} \mathrm{C}$ (Exp. 1). Casein (TCA-N) recovered initially increased in Exp. 2 from $21 \%$ at $3 \mathrm{~g}$ to $86 \%$ at $12 \mathrm{~g}$ TCA-N, while absolute loss remained relatively constant at $358 \mathrm{mg}$ TCA-N/kg RC (SD = 47). Fractional degradation rate was highest (0.03/min) at the intermediate dosage level. In the absence of rumen fluid (Exp. 4), no casein was lost. Initial egg protein recovery was on average 103\% (Exp. 3). Recovery 
24

seemed unaffected by dosage level, absolute degradation rate was relatively constant over time and increased with dosage level $(\mathrm{P}<0.001)$ from 1.48 to $2.95 \mathrm{mg}$ TCA-N $/\left(\mathrm{kg}\right.$ RC $t_{\underline{x}}$ min $)$. Maximum degradation rate (mg TCA-N/(kg RC x min)TCA N/kg RC/min) and affinity constant (mg TCA-N/kg RC-)were estimated at 261 and 1650 , respectively. It is concluded that a surprisingly constant amount of casein disappears immediately from warm rumen fluid and that this does not occur either with chilled rumen contents, in the absence of rumen fluid or when replaced with egg protein. The mechanisms for this disappearance are yet to be discovered.

Running head: Soluble protein degradation in vitro

Keywords: Macro in vitro; Protein degradation; Rumen; Casein; Egg albumin

Correspondence: P. Udén, Department of Animal Nutrition \& Management, Kungsängen Research Centre, Swedish University of Agricultural Sciences, S-753 23 Uppsala, Sweden.

Tel: +46 (0)18672058; Fax: +46(0)18672946; E-mail: peter.uden@ slu.se

\section{Introduction}

Protein quality is an important variable in optimization of ruminant diets. Even though lack of key amino acids may limit milk production, the proportion of feed protein degraded in the rumen (effective protein degradation) and the availability of the feed protein passing from the rumen are normally the major protein quality criteria in use. Degradability of protein can be estimated in vivo, but these techniques are expensive, time-consuming and labour intensive. 
46 There are also considerable problems inherent to these methods in separating feed and

47 microbial protein and in evaluating proteins from single feeds.

48

In most evaluation systems, the soluble fraction is considered to be completely degraded in the rumen (e.g. Sniffen et al., 1992). Findings by Volden et al. (1998) showed, however, that approximately $10 \%$ of infused free amino acids may escape the rumen. A soluble protein such as casein with an assumed fermentation rate of $1 / \mathrm{h}$ and a liquid passage rate of $0.16-/ \mathrm{h}$ would result in a rumen escape of approximately $15 \%$, whereas with the slower fermentation rate of soluble rapeseed cake protein $(0.19 / \mathrm{h})$, the estimated escape would be $46 \%$ (Hedqvist and Udén, 2006).

The method of Hedqvist and Udén (2006) is a relatively simple method, similar to that of Broderick (1987) but without the use of bacterial growth inhibitors, to measure soluble protein degradation. Remaining soluble protein is precipitated from the bacteria-free supernatant to recover remaining feed proteins after fermentation. One major problem was encountered in this study. The recoveries of soluble proteins from 11 sources at 20 or $30 \mathrm{~min}$ were low and on the order of 25 to $36 \%$ and after 1 to $2 \mathrm{~h}$ of incubation, levels became difficult to separate from background.

A novel macro-in vitro method was introduced by Udén (2011) in a study on volatile fatty acid production. In this system, 5 to $10 \mathrm{~kg}$ of whole rumen contents can be used which enables continuous sampling of fluids and ensures a more rumen-like environment as compared to regular micro-systems using small amounts of strained rumen fluid.

The aim of this study was therefore to explore the macro-in vitro system for studying degradation of two soluble proteins and to investigate the phenomenon of initial disappearance of proteins from solution. 
Materials and methods

Three in vitro rumen experiments and one experiment without rumen fluid were made to study the degradation of soluble proteins. Exp. 1 was a pilot study to confirm previous findings of low recoveries of soluble proteins both in vitro and in vivo (Hedqvist and Udén, 2006) and to study the effect of normal and low temperature on initial disappearance. In Exp.

2, four levels of casein and in Exp. 3, four levels of egg albumin were studied at normal rumen temperature. To test the possibility of attachment of casein to feed particles, casein was incubated with silage at normal rumen temperature in Exp. 4.

Proteins and inocula source

The casein used was bovine sodium caseinate (Sigma, CAS 9005-46-3; Sigma-Aldrich Sweden AB, Stockholm, Sweden) and the egg albumin was 'Egg Protein 80' (Olimp Sport Nutrition AB, Partille, Sweden). One dry and one lactating cow, fitted with rumen cannulas, were used as donors of rumen contents (RC). The dry cow consumed daily $3.4 \mathrm{~kg}$ dry matter (DM) grass hay with a crude protein content (CP) of $155 \mathrm{~g} / \mathrm{kg}$ DM and $1.6 \mathrm{~kg}$ concentrates (CP: $200 \mathrm{~g} / \mathrm{kg} \mathrm{DM}$ ). The lactating cow consumed 15 to $16 \mathrm{~kg}$ DM from a grass dominated silage (CP: $161 \mathrm{~g} / \mathrm{kg}$ DM) and $7 \mathrm{~kg} \mathrm{DM}$ of a concentrate mix (CP: $200 \mathrm{~g} / \mathrm{kg} \mathrm{DM})$. All cows had free access to water and salt licks.

The in vitro system

A macro in vitro system was used for all incubations as described by Udén (2011), but with the following modifications: i) eight instead of two tubes with the inner dimensions $(\mathrm{cm})$ 76(height) x 18.8(diameter) made of $6 \mathrm{~mm}$ hard polyethylene, ii) the insulated heated box was 
94

made from 5-cm Styrofoam ${ }^{\mathrm{TM}}$ with the inner dimensions $(\mathrm{cm}) 110$ (length) $\mathrm{x} 55$ (width) $\mathrm{x}$ 60(height), iii) the mixer consisted of a grain auger $(\mathrm{cm}) 50$ (length) and 10 (diameter) with 8 turns $/ \mathrm{m}$ and a $45-\mathrm{cm}$ shaft extending through the centre hole of the lid, and iv) the whole assembly including heater was mounted on a pallet for easy transport between in vitro room and stable.

The following general protocol was used for the in vitro incubations:

1. Day before the experiment: prepare sufficient quantities of McDougall's buffer (McDougall, 1948). Fill glass jars with 2-L of the buffer (blank) or the protein in question dissolved in the same amount of buffer. Record tare weights of in vitro tubes and assemble the in vitro unit. Add $2 \mathrm{~L}$ of pure McDougall's buffer to all tubes, gas with $\mathrm{CO}_{2}$, seal the lids, and heat over night with the thermostat set at $39^{\circ} \mathrm{C}$. Bubble $\mathrm{CO}_{2}$ in all solutions over night. 2. Experimental day: add more $\mathrm{CO}_{2}$ and move in vitro assembly to the stable and plug in heater. Record rumen $\mathrm{pH}$ and transfer whole $\mathrm{RC}$ from rumen fistulated cow(s) to each in vitro tube with minimum exposure to air.

3. Move assembly back to the in vitro room and plug in heater again. Add more $\mathrm{CO}_{2}$ and pour the first solution (blank or protein solution) into in vitro tube no 1.

4. Start timer, mix the in vitro contents vigorously for $30 \mathrm{sec}$ and take a $50-\mathrm{mL}$ sample of the liquid fraction by aspiration (see Udén, 2011). Record pH and cool sample rapidly in ice bath. Continue with the tube no 2 and solution no 2, etc. Space samplings 2.5 min apart, which will allow for a minimum time interval of 20 min for each tube when using a total of 8 tubes.

5. Sample again according to schedule and continue sampling for a maximum of $3 \mathrm{~h}$.

6. Centrifuge samples at $1500 \mathrm{x} \mathrm{g}$ for $5 \mathrm{~min}$ and split the supernatant into one 30 - and one 15-mL sample. Transfer supernatants to refrigerator $\left(4^{\circ} \mathrm{C}\right)$ and analyze for total $\mathrm{N}, \mathrm{NH}_{3}-\mathrm{N}$ and 
trichloroacetic acid precipitable N (TCA-N) following morning as specified under 'Sample analyses'.

7. Record weights of the in vitro tubes and determine DM concentrations of remaining ingesta.

\section{Experiment 1}

Two separate incubations with two tubes each were made. Rumen contents from the lactating cow was removed and the amount adjusted to $5 \mathrm{~kg}$ (Table 1) for each in vitro tube in both incubations. In both incubations, $7.25 \mathrm{~g}$ dissolved casein (air dry weight) was added to one of the tubes and only buffer to the other (blank). In the first incubation, the protocol described above was followed, except that the amount of buffer used in Step 3 was only 1 L. Samples were taken at 3, 30, 60, 90, 120 and 180 min during the incubation. In the second incubation, the procedure differed on the following accounts. Rumen contents, buffer, casein solution and in vitro assembly were chilled to $2^{\circ} \mathrm{C}$ before adding the casein or blank solutions to the RC.

These tubes were then kept in the insulated box with ice bags to maintain the $2^{\circ} \mathrm{C}$ temperature during the entire measurement period. Samples were taken at 3, 60, 120 and $180 \mathrm{~min}$.

\section{Experiment 2 and 3}

Casein was incubated at 0,20, 40 or $80 \mathrm{~g} /$ tube in duplicate (a total of 8 tubes) in Exp. 2 and egg powder was used in Exp. 3 at the levels of 1, 60, 120 and $240 \mathrm{~g} /$ tube (Table 1). The higher levels used for egg protein were due to a suspicion that detection of any saturation kinetics would require higher levels of this slow-degrading protein as opposed to casein. Incubation times used were 2, 20, 40, 60, 80, 120 and 180 min in Exp. 2 and 1, 18.5, 38.5, 58.5, 91, 121 and $181 \mathrm{~min}$ in Exp. 3. Approximately $7 \mathrm{~kg} \mathrm{RC}$ from the dry cow was used for 
142 one of the replicates and RC from the lactating cow was used for the other. The amounts

143 actually incubated are shown in Table 1 and samples were handled as in the protocol above.

144

145

146

147

148

149

150

151

152

153

154

155

156

157

158

159

160

161

162

163

164

165

\section{Experiment 4}

One-hundred grams of chopped silage with a dry matter content of $346 \mathrm{~g} / \mathrm{kg}$ were placed in three Erlenmeyer flasks and heated in an oven at $60^{\circ} \mathrm{C}$ oven overnight to eliminate bacterial activity. On the following day, flasks were equilibrated to $39^{\circ} \mathrm{C}$ in a water bath, followed by the addition of $600 \mathrm{~mL}$ sterile $39^{\circ} \mathrm{C}$ McDougall's buffer containing either (two flasks) 1000 mg casein or no casein (one flask; blank). Sub-samples (35 mL) were taken after 3, 30, 90 and 180 min and handled as described above.

Sample analysis

In vitro tube RCs remaining after the incubations were dried at $55^{\circ} \mathrm{C}$ and weighed to estimate liquid volume in each tube. Total liquid volumes were calculated after adjustment for volumes removed during sampling.

In vitro supernatants were analyzed for $\mathrm{NH}_{3}-\mathrm{N}$ in Exp. 2 and 3 (only for the 0, 60, 120 and 180 min samples), and in all samples for total soluble $\mathrm{N}$ and for TCA-N (except for Exp. 4). Liquid samples from the previous day (Exp. 1-3) were first centrifuged at $25000 \mathrm{x} g$ for 15 min at $4^{\circ} \mathrm{C}$. From the $15-\mathrm{mL}$ supernatant, $3 \mathrm{~mL}$ was-were taken for $\mathrm{NH}_{3}-\mathrm{N}$ analysis and $7 \mathrm{~mL}$ wasere frozen and saved. Ammonia-N was analyzed by the phenol-hypochlorite assay using flow-injection analysis (FIAstar ${ }^{\mathrm{TM}}$ 5012, Foss Analytical, Hillerød, Denmark).

The 30-mL sample was split into 12.5 and $10 \mathrm{~mL}$ sub-samples. To the $12.5-\mathrm{mL}$ sample, 1.5 mL TCA (1000 g/L) was added and the mixture was put on ice for $1 \mathrm{~h}$. This was followed by centrifugation at $25000 \mathrm{xg}$ for $15 \mathrm{~min}$ at $4^{\circ} \mathrm{C}$. Both the supernatant after precipitation with 
TCA and the untreated supernatant $(10 \mathrm{~mL})$ were transferred to glass test tubes for $\mathrm{N}$ analysis by the Kjeldahl procedure (Foss Tecator 2020 Digester and 2400 Kjeltec Analyzer unit, Hillerød, Denmark), using copper as a catalyst. Amounts of TCA-precipitable N (TCA-N) were calculated by difference.

\section{Biometric analysis}

All $\mathrm{NH}_{3}$ - and TCA-N values were blank corrected after adjustments for volume differences among the in vitro blank and treatment tubes. Soluble $\mathrm{N}$ values were only recorded in Exp. 4 and were blank corrected before calculating recoveries.

As exponential degradation was assumed used for the disappearance of casein TCA-N (Exp. 2), a single exponential function was fitted to the individual data from all 6 treatment tubes by TableCurve ${ }^{\mathrm{TM}}$ TD (Jandel Scientific, San Rafael, CA, USA), using standard least-squares minimization:

$\mathrm{Y}=\mathrm{a}+\mathrm{bxe} \mathrm{e}^{(-\mathrm{c} * \mathrm{t})}$ where, 'Y' = recovery of TCA-N, 'a' = curve asymptote, 'b' = y-axis intercept, 'c' = degradation rate (/min) and 't' = time (min).

Both egg protein disappearance (Exp. 3) and $\mathrm{NH}_{3}-\mathrm{N}$ appearance (Exp. 2 and 3) were linear in fashion during the 3-h measurement periods and did not fit the exponential equation that was used for casein results. Therefore, only linear regressions were fitted to the 6 treatment data sets using Minitab® v. 15 (Minitab Inc., State College, PA, USA) and tested for similarities among slopes.

To test if saturation kinetics prevailed, the Michaelis-Menten equation was fitted to both protein sources, combining data from the two cows and three protein levels. Degradation velocity for egg protein was calculated as the slope of the TCA-N concentration $(\mathrm{mg} \mathrm{N} / \mathrm{kg}$ 
190

191

192

193

194

195

196

197

198

199

200

201

202

203

204

205

206

207

208

209

210

211

212

$\mathrm{RC}$ ) versus dosage (mg TCA-N/kg RC; $\mathrm{n}=6$ ). Casein degradation was calculated as the change in TCA-N concentration (mg N/kg RC) between each measurement versus remaining casein concentration (mg TCA-N/kg RC; $\mathrm{n}=42$ ) at the beginning of each sampling period. Maximum degradation rate $\left(\mathrm{V}_{\max } ; \mathrm{mg}\right.$ TCA-N/(kg RC x min $\left.) \mathrm{TCA} \mathrm{N/kg} \mathrm{RC/min}\right)$ and the affinity constant $\left(\mathrm{k}_{\mathrm{m}} ; \mathrm{mg}\right.$ TCA-N/kg RC) were estimated using the Solver function in Microsoft Excel® to minimize $\Sigma(\text { estimated - measured rate })^{\wedge} 2$.

Data of degradation rate as affected by initial protein level was analyzed by simple regression analysis using Minitab®. Significant polynomial effects were considered at probabilities less than 0.05 .

\section{Results}

The casein contained $148 \mathrm{mg}$ and the egg powder $103 \mathrm{mg}$ TCA-N/g air dry matter. Data on achieved dosage levels, weights of RC collected and total fluid volumes in the in vitro vessels are shown in Table 1.

\section{Experiment 1}

The recovery of a low dosage of casein TCA-N at two temperatures is shown in Fig. 1. There was a marked difference in the recovery at 2 and $39^{\circ} \mathrm{C}$ at the first sampling time ( $\left.3 \mathrm{~min}\right)$ with a value of $106 \%$ at $2{ }^{\circ} \mathrm{C}$ and $56 \%$ at $39^{\circ} \mathrm{C}$. Corresponding recoveries at 30 min were 88 and $14 \%$, respectively.

\section{Experiment 2 and 3}

Initial recovery of TCA-N 
213 Recoveries of casein TCA-N at the first sampling time (2 min) increased dramatically with

214 increasing dosage from 16 and $27 \%$ at approximately $500 \mathrm{mg} / \mathrm{kg} \mathrm{RC}$ (Treatment 3) to 84 and

$21587 \%$ at approximately $1700 \mathrm{mg}$ TCA-N/kg RC (Treatment 12) with RC from the dry and

216 lactating cow, respectively (Fig. 2). In absolute terms, this recovery equaled a mean loss of

$217358 \mathrm{TCA}-\mathrm{N} \mathrm{mg} / \mathrm{kg}$ fresh weight RC after one minute of incubation and was relatively

218 constant for all dosage levels $(\mathrm{SD}=47 ; \mathrm{n}=6)$. Egg protein TCA-N recovery after 1 min was

219 on average $103 \%$ and seemed unaffected by dosage level (Fig. 2).

220 Degradation of TCA-N

221 Curves for net TCA-N are shown in Fig. 3 and 4. Casein disappeared in a curvilinear fashion

222 and fractional disappearance rates ('c') changed with dosage level. Rate $v s$. dose level was

223 explained by a polynomial regression $\left(\mathrm{R}^{2}=0.977\right)$ where the quadratic term of the regression 224 equation differed from zero $(\mathrm{P}=0.002)$.

225 Egg protein degradation was relatively constant over time for both inocula. Degradation 226 increased linearly with dosage level (linear term: $\mathrm{P}<0.001)$ from an average of 1.48 for the 227 lowest level to $2.95 \mathrm{mg}$ TCA-N/(kg RC x min) TCA-N/kg RC/min-for the highest dosage level (Table 3). The increase appeared to be curvilinearly related to dosage level, suggesting

229 saturation kinetics. Applying the Michaelis-Menten equation to the egg protein data, resulted 230 in a $\mathrm{V}_{\max }$ estimate of $261 \mathrm{mg}$ TCA-N $/\left(\mathrm{kg} \mathrm{RC} \times\right.$ min) $\mathrm{TCA} \mathrm{N} / \mathrm{kg} \mathrm{RC} / \mathrm{min}$ and a $\mathrm{k}_{\mathrm{m}}$ of $1650 \mathrm{mg}$

231 TCA-N/kg RC as shown in Fig. 5. The casein data did not fit the Michaelis-Menten equation.

232 Initial rates differed markedly from subsequent rates and even after removal of all first

233 observations, disappearance was directly proportional to vessel concentrations.

234 Ammonia production

235 Ammonia-N evolutions are also presented in Fig. 3 and 4 and showed correspondence with

236 the differences in TCA-N disappearance of the two proteins. The increases in concentrations 
over time were similar for all dosage levels and approximately linear for both proteins, with the exception for the lowest casein dose (Treatment 3), which seemed to level off after 60 min. Removing casein values for Treatment 3 at time $>60 \mathrm{~min}$ and regressing ammonia levels against fermentation time, gave slopes of $1.44 \pm 0.061$ and $0.52 \pm 0.023 \mathrm{mg} \mathrm{NH}_{3}-\mathrm{N} / \underline{\mathrm{kg} \mathrm{RC}} \underline{\mathrm{x}}$ $\min 2\left(\mathrm{R}^{2}>0.95\right)$ for casein and egg protein, respectively.

\section{Experiment 4}

The incubation of casein without rumen fluid showed that recovery of soluble $\mathrm{N}$ did not change over time and was on average $99 \%$ with a range of 95 to $104 \%$.

\section{Discussion}

Measuring protein degradation has been a great challenge over the past decades and no method has yet received wide acceptance by the scientific community. The in sacco technique (e.g. Mehrez and Ørskov, 1977) is the dominating method for estimating rumen protein degradability. The method is labour intensive, cannot be applied to soluble proteins and has inherent problems with microbial $\mathrm{N}$ contamination and feed particle loss of undegraded $\mathrm{N}$ from the bags (Lopez, 2005).

Various in vitro systems have been introduced over the past decades. Some of their major shortcomings are listed in Table 4. In the Cornell Net Carbohydrate and Protein System, Sniffen et al. (1992) separated crude protein into five fractions based on their buffer and detergent solubility and linked these with estimated in vitro enzyme degradation rates (Krishnamoorthy et al.,1983). The method is attractive for reasons of low cost and simplicity but doubt exists as to the similarity of fungal enzyme and bacterial protein degradation. The inhibitor in vitro (IIV) system of Broderick (1987) measures appearance of amino acids and 
261

262

263

264

265

266

267

268

269

270

271

272

273

274

275

276

277

278

279

280

281

282

283

284

285

ammonia in the presence of inhibitors of bacterial protein synthesis. The method is suitable for incubations of approximately 3 to $4 \mathrm{~h}$ and can give sufficient data for meaningful rate estimates, provided that protein degradation rates are high. The gas in vitro method of Raab et al. (1983) estimates protein degradation from ammonia evolution at graded levels of carbohydrate additions but is both expensive, complex and time consuming in its original form. The authors have presented mainly 24-h incubations and short incubation times were not investigated to any degree. Some improvements to this method were made recently by Karlsson et al. (2009) and Lorenz et al. (2011) to estimate degradation continuously up to 30 $\mathrm{h}$ in the same flask. However, the method has not yet been developed as a reliable routine method for protein rate estimations.

Soluble proteins have generally been regarded as being instantly degraded in the rumen (Krishnamoorthy, 1983) even though Volden et al. (1998) demonstrated that even amino acids could escape rumen fermentation at a level of $10 \%$. These proteins can be separated from bacterial protein by high-speed centrifugation and measured as loss of proteins from solution (Hedqvist and Udén, 2006) without the need of inhibitors of protein synthesis, which should be an advantage in terms of maintaining bacterial activity over a longer time compared to the IIV method.

In the present study, the normal size in vitro system of approximately $50 \mathrm{~mL}$ was abandoned in favor of a macro system with whole rumen contents. This was done in order to create an environment in vitro as close to in vivo conditions as possible. The major drawbacks are a limited fermentation time of approximately $3 \mathrm{~h}$, only applicable to soluble proteins and a reduced number of vessels/run. The large proportions of soluble proteins disappearing before $30 \mathrm{~min}\left(1^{\text {st }}\right.$ sampling) of fermentation in the study of Hedqvist and Udén (2006) were also confirmed for casein in the present study. Disappearance occurred before 3 min of incubation but at $2^{\circ} \mathrm{C}$, recovery was approximately complete (Fig. 1) and recovery was also 
approximately $100 \%$ when no rumen fluid was present. Similar casein levels were used in Exp. 1 (approximately $250 \mathrm{mg}$ N/L rumen fluid) as in the study of Hedqvist and Udén (2006) where levels ranged from 100 to $200 \mathrm{mg}$ N/L strained rumen fluid. When casein levels were further increased in Exp. 2, initial recoveries improved asymptotically (Fig. 2) and from these data, a loss of approximately $358 \mathrm{mg}$ TCA-N $/ \mathrm{kg}$ fresh weight of RC was evident. Adsorption of soluble protein was reported to occur also at low temperatures when proteolytic activity is at a minimum (Nugent and Mangan, 1981; Wallace, 1985). Wallace (1985) reported a maximum binding capacity of $10 \mu \mathrm{g}$ casein/mg bacterial protein. However, in the study of Hedqvist and Udén (2006), this level was estimated to account only for an initial binding of $6 \%$ and could not explain the large initial casein loss. Casein structure is unique and caseins are highly surface active forming both micelles and gels under certain conditions (Horne, 2002). The drastic reduction in initial disappearance when cooling the RC in the present study can presently only be explained by attachment. It is unlikely that regular precipitation would have been higher at 39 than at $2^{\circ} \mathrm{C}$.

Protein degradation involves a number of steps before the protein has been completely metabolized. Casein in vitro data from Broderick and Craig (1989) was used by Udén (2000) to formulate a model consisting of three extracellular (protein, peptides and amino acids), one intracellular (amino acids) and one total ammonia N-pool. Parameter estimations of the model revealed that degradation of casein to peptides and the uptake of peptides had similar rates. It was therefore concluded that estimating ruminal protein degradation from the appearance of $\mathrm{N}$ in the form of fermentation end-products (ammonia and amino acids) may not be correct using a one-pool model.

As protein degradation is defined according to method employed, rate estimates may differ irrespective of proteolytic activity. Appearance of amino acids and/or ammonia is used in both the IIV system of Broderick (1987) and in the gas-in vitro system of Raab et al (1983). 
311 Loss of TCA-precipitable $\mathrm{N}$ was used in the method of Hedqvist and Udén (2006) and in the

312 present study. In electrophoretic studies, loss of specific proteins are defined as degradation

313 (e.g. McNabb, 1994; Messman and Weiss, 1994). Using appearance of e.g. ammonia by the

314 gas-in vitro method includes both the degradation of protein to peptides and amino acids,

315 absorption and catabolism. Disappearance measurements by in vitro or electrophoretic

316 methods assume that degradation has occurred when the protein has been sufficiently reduced

317 in size to resist precipitation, or is too small for electrophoretic detection. As an important

318 goal of protein degradation measurements is the prediction of feed amino acid delivery to the

319 small intestine, it seems logical that residual feed $\mathrm{N}$ in all forms from amino acids to intact

320 proteins should be the ideal target. All present in vitro methods based on protein loss, ignore

321 degradation beyond the lowest size detection limit which is particularly serious for the

322 electrophoretic methods.

323 Fractional disappearance of casein (TCA-N) was rapid $(0.91$ to $1.75 / \mathrm{h})$ in the present study

324 and highest at the intermediate level (Table 2). The reason for a higher fractional degradation

325 at the intermediate level is not easily understood. Levels used were approximately equivalent

326 to 270 to $1020 \mathrm{~g}$ of soluble protein to a cow with $100 \mathrm{~kg}$ of rumen contents. Within this range

327 of casein levels, no evidence could be found for any saturation phenomena. Broderick and

328 Clayton (1992), however, found evidence of saturation kinetics for casein degradation with

329 similar levels as in Exp. 2 using the inhibitor in vitro method. When they estimated rate as

$330 \mathrm{~V}_{\mathrm{max}} / \mathrm{k}_{\mathrm{m}}$ from this experiment, casein degradation rate approached $1.0 / \mathrm{h}$. This rate estimate

331 should be the theoretical rate at an infinitesimal substrate level. Conventional rate estimations

332 have shown considerably lower rates, normally less than 0.4 /h (Broderick and Clayton, 1992;

333 Broderick et al., 2004a, b).

334 Both inoculas displayed similar degradation rates. The lactating cow consumed 4.5 times (22

335 to $23 \mathrm{~kg} \mathrm{DM}$ ) as much feed as the cow at maintenance but, as the comparison was restricted to 
two cows, it cannot be regarded as a final proof of no difference. In the study of Broderick et al. (2004a) using casein, solvent soybean meal and expeller soybean meal, two feeding levels (1X and $3 \mathrm{X}$ maintenance) and three inocula sampling times (0, 2 and $4 \mathrm{~h}$ after feeding), there was an overall effect of feeding level $(\mathrm{P}<0.001)$ as well as a time and a time $\mathrm{x}$ level effect of the inocula on all individual feeds $(0.001<\mathrm{P}<0.032)$.

Egg protein initial recoveries seemed unaffected by levels above $800 \mathrm{mg} \mathrm{N} / \mathrm{kg} \mathrm{RC}$, but the choice of protein levels prohibited detection of any minor protein losses. Ovalbumin is found mainly in egg white and its structure belongs to the serpin family. The proteins in this family are known for binding to enzymes and immobilizing them, but ovalbumin itself does not possess any protease inhibitory effects (Huntington and Stein, 2001). In spite of this, degradation of ovalbumin is very slow (McNabb et al., 1994) which was confirmed in the present study. McNabb et al. (1994) found a discrete lag phase of $16 \mathrm{~h}$ and a rate of $0.08 \mathrm{~h}$ for the intact protein bands in their in vitro study. In the present study, no obvious lag phase was seen and degradation proceeded linearly within the 3-h incubation. The fact that egg protein rate seemed to display saturation kinetics (Fig. 5) in contrast to casein (Fig. 6) may suggest limited microbial enzyme capacity for this protein.

\section{Conclusions}

Casein behaved totally different from egg protein by displaying an immediate disappearance from the precipitable fraction of the in vitro supernatant at a level of $358 \mathrm{TCA}-\mathrm{N} \mathrm{mg} / \mathrm{kg}$ fresh weight of RC. For egg protein and for casein incubated at $2^{\circ} \mathrm{C}$, initial recovery was nearly complete. Increasing casein dosages made estimates of recovery more reliable, but the estimated rate differed with dosage and was highest at the intermediate level (6 g N/tube). Egg protein degraded linearly and displayed evidence of saturation kinetics, whereas this could not be demonstrated for casein. The macro-in vitro system appears to be a promising in 
361 terms of ease of handling and operates under more rumen-like conditions. The drawbacks are

362 reduced number of vessels and that only short incubation times with soluble substrates are

363 presently possible

Acknowledgments

366

367

368

369

370

371

372

373

374

375

376

377

378

379

380

381

382

383

The author gratefully acknowledges support from The Swedish Farmers' Foundation for Agricultural Research for the project V0530019.

\section{References}

Broderick, G. A., 1987: Determination of protein degradation rates using a rumen in vitro system containing inhibitors of microbial nitrogen metabolism. British Journal of Nutrition 58, 463-475.

Broderick, G.A.; Clayton, M.K., 1992: Rumen protein degradation rates estimated by nonlinear regression analysis of Michaelis-Menten in vitro data. British Journal of Nutrition 67, $27-42$.

Broderick, G. A.; Craig, W. M., 1989: Metabolism of peptides and amino acids during in vitro protein degradation by mixed rumen organisms. Journal of Dairy Science 72, 2540-2548.

Broderick, G.A.; Murphy, M.L, Udén, P., 2004a: Effect of inhibitor concentration and endproduct accumulation on estimates of ruminal in vitro protein degradation. Journal of Dairy

Science 87, 1360-1371.

Broderick, G.A.; Udén, P.; Murphy, M.L.; Lapins, A., 2004b: Sources of variation in rates of in vitro ruminal protein degradation. Journal of Dairy Science 87, 1345-1359. 
384 Hedqvist, H.; Udén, P., 2006: Measurement of soluble protein degradation in the rumen.

385 Animal Feed Science and Technology 126, 1-21.

386 Horne, D.S., 2002: Casein structure, self-assembly and gelation. Current Opinion in Colloid 387 and Interface Science 7, 456-461.

388

389

390

391

392

393

394

395

396

397

398

399

400

401

402

403

404

405

406
Huntington, J.A.; Stein, P.E., 2001: Structure and properties of ovalbumin. Journal of

Chromatography B 756, 189-198.

Karlsson, L.; Hetta, M.; Udén, P.; Martinsson, K., 2009: New methodology for estimating rumen protein degradation using the in vitro gas production technique. Animal Feed Science and Technology 153, 193-202.

Krishnamoorthy, U.; Sniffen, C.J.; Stern, M.D.; Van Soest, P.J., 1983: Evaluation of a mathematical model of rumen digestion and an in vitro simulation of rumen proteolysis to estimate the rumen-undegraded nitrogen content of feedstuffs. British Journal of Nutrition 50, 555-568.

Lopez, S., 2005: In vitro and in situ techniques for estimating digestibility. In: Dijkstra, J.;

Forbes, J.M.; France, J. (eds.), Quantitative Aspects of Ruminant Digestion and Metabolism.

CABI Publishing, Wallingford, UK.

Lorenz, M.M., Karlsson, L., Hetta, M., Udén, P., 2011. Recycling of microbial N and estimation of protein degradation by in vitro gas production. Animal Feed Science and Technology 170, 111- 116.

McDougall, E. I., 1948: Studies on ruminant saliva. I. The composition and output of sheep's saliva. Biochemical Journal 43, 99-109.

McNabb, W.C.; Spencer, D.; Higgins T.J.; Barry, T.N., 1994: In vitro rates of rumen proteolysis of ribulose-1,5-bisphosphate carboxylase (Rubisco) from lucerne leaves, and of 
407

408

409

410

411

412

413

414

415

416

417

418

419

420

421

422

423

424

425

426

427

428

429

430

ovalbumin, vicilin and sunflower albumin 8 storage proteins. Journal of the Science of Food and Agriculture 64, 53-61.

Mehrez, A.Z.; Ørskov, E.R., 1977: A study of the artificial fibre bag technique for determining the digestibility of feeds in the rumen. Journal of Agricultural Science (Cambridge) 88, 645-650.

Messman, M.A.; Weiss, W.P., 1994. Use of electrophoresis to quantify ruminal degradability of protein from concentrate feeds. Animal Feed Science and Technology 49, 25-35.

Nugent ,J.H.A.; Jones, W.T.; Jordan, D.J.; Mangan, J.L., 1983: Rates of proteolysis in the rumen of the soluble proteins casein, fraction 1 leaf protein, bovine serum albumin and bovine submaxillary mucoprotein. British Journal of Nutrition 50, 357-368.

Nugent, J.H.A.; Mangan, J.L., 1981: Characteristics of the rumen proteolysis of fraction 1 (18S) leaf protein from lucerne (Medicago sativa L.). British Journal of Nutrition 46, 39-58.

Raab, L.; Cafantaris, B.; Jilg, T.; Menke, K.H., 1983: Rumen protein degradation and biosynthesis 1 . A new method for determination of protein degradation in rumen fluid in vitro. British Journal of Nutrition 50, 569-582.

Sniffen, C.J.; O’Connor, J.D.; Van Soest, P.J.; Fox, D.G.; Russel, J.B., 1992: A net carbohydrate and protein system for evaluating cattle diets: II. Carbohydrate and protein availability. Journal of Animal Science 70, 3562-3577.

Spencer, D.; Higgins, T.J.V.; Freer, M.; Dove, H.; Coombe, J.B., 1988: Monitoring the fate of dietary proteins in rumen fluid using gel electrophoresis. British Journal of Nutrition 60, 241247.

Udén, P., 2000: Ruminal metabolism of buffer soluble proteins, peptides and amino acids in vitro. In: McNamara, J.; France, J.; Beever, D. (eds.). Modelling Nutrient Utilization in Farm Animals, CABI Publ., Wallingford, UK, pp. 63-72. 
431 Udén, P., 2011: Using a novel macro in vitro technique to estimate differences in absorption 432 rates of volatile fatty acids in the rumen. Journal of Animal Physiology and Animal Nutrition $433 \quad \mathbf{9 5}, 27-33$

434 Volden, H.; Velle, W.; Harstad, O.M.; Aulie, A.; Sjaastad, V., 1998: Apparent ruminal 435 degradation and rumen escape of lysine, methionine, threonine administered intraruminally in 436 mixtures to high yielding cows. Journal of Animal Science 76, 1232-1240.

437 Wallace, R.J., 1985: Adsorption of soluble proteins to rumen bacteria and the role of 438 adsorption in proteolysis. British Journal of Nutrition 53, 399-408. 
Table 1 Dosage levels of casein and egg protein, amounts of fresh rumen contents (RC) and liquid volumes obtained from a dry and/or lactating cow in Exp. 1 to 3. Treatment numbers refer to approximate TCA-N dosages in $\mathrm{g} /$ tube

\begin{tabular}{|c|c|c|c|c|c|c|c|c|c|}
\hline \multirow{3}{*}{ Treatment } & \multicolumn{3}{|c|}{ Dosage } & \multicolumn{3}{|c|}{ Dry cow } & \multicolumn{3}{|c|}{ Lactating cow } \\
\hline & Air dry weight & Soluble N & TCA-N & $\mathrm{RC}$ & Liquids $^{*}$ & TCA-N $\dagger$ & $\mathrm{RC}$ & Liquids $^{*}$ & TCA-N† \\
\hline & $\mathrm{g}$ & $\mathrm{g}$ & g & $\mathrm{kg}$ & L & $\mathrm{mg} / \mathrm{kg} \mathrm{RC}$ & $\mathrm{kg}$ & $\mathrm{L}$ & $\mathrm{mg} / \mathrm{kg} \mathrm{RC}$ \\
\hline \multicolumn{10}{|c|}{ Exp. 1 - casein } \\
\hline 0 & 0 & 0 & 0 & & & & 5.00 & 7.21 & \\
\hline 1 & 7.25 & 1.09 & 1.07 & & & & 5.00 & 7.28 & 214 \\
\hline \multicolumn{10}{|c|}{ Exp. 2 - casein } \\
\hline 0 & 0 & 0 & 0 & 6.80 & 10.05 & 0 & 6.53 & 9.67 & \\
\hline 3 & 20 & 3.02 & 2.96 & 6.92 & 10.19 & 428 & 6.35 & 9.56 & 466 \\
\hline 6 & 40 & 6.04 & 5.92 & 6.94 & 10.22 & 853 & 6.51 & 9.75 & 909 \\
\hline 12 & 80 & 12.08 & 11.84 & 7.31 & 10.47 & 1620 & 6.46 & 9.65 & 1830 \\
\hline \multicolumn{10}{|c|}{ Exp. 3 - egg protein } \\
\hline 0 & 0 & 0 & 0 & 7.65 & 10.79 & 0 & 7.48 & $10.5 \mathrm{~s}$ & \\
\hline 6 & 60 & 7.14 & 6.42 & 7.75 & 10.60 & 828 & 7.34 & 10.40 & 875 \\
\hline 12 & 120 & 14.28 & 12.84 & 7.66 & 10.62 & 1680 & 7.46 & 10.46 & 1720 \\
\hline 24 & 240 & 28.56 & 25.68 & 7.01 & 9.90 & 3660 & 7.56 & 10.40 & 3400 \\
\hline
\end{tabular}

†Trichloroacetic acid 
Table 2 Exp2: Parameters obtained from fitting an exponential function* to the recovery data of casein TCA-N (Fig. 3) from in vitro incubation with rumen contents from a dry and a lactating cow and three levels of casein ( 3,6 and $12 \mathrm{~g}$ of TCA-N/tube)

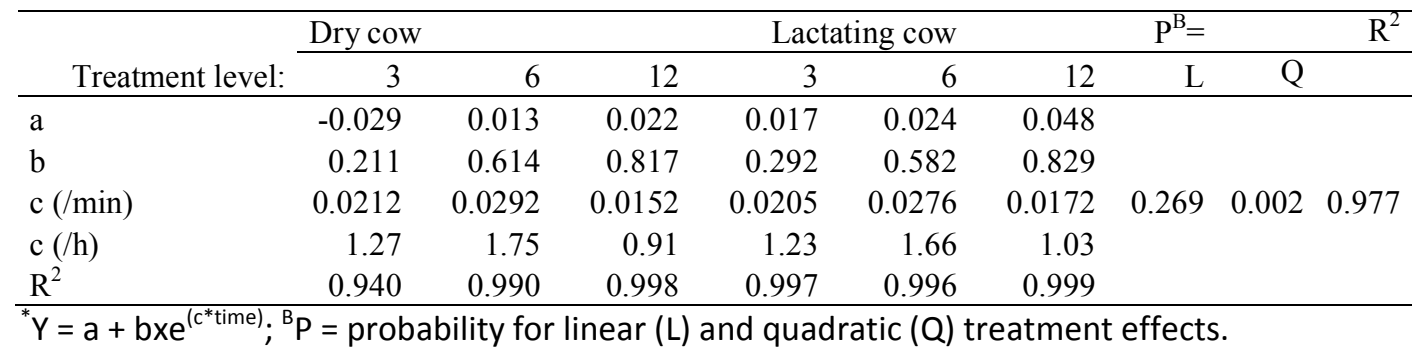


Table 3 Exp 3: Linear regression of TCA-N ( $\mathrm{mg} / \mathrm{kg}$ rumen contents) upon time ( $\mathrm{min}$ ) from in vitro incubation of egg protein (Fig. 4) with rumen contents from a dry and a lactating cow and three levels of egg protein $(6,12$ and $24 \mathrm{~g}$ of TCA-N/tube)

\begin{tabular}{lrrrrrrrrr}
\hline & \multicolumn{2}{c}{ Dry cow } & \multicolumn{4}{c}{ Lactating cow } & $\mathrm{P}^{*}=$ & $\mathrm{R}^{2}$ \\
\cline { 2 - 10 } Treatment: & 6 & 12 & 24 & 6 & 12 & 24 & Linear & \\
\hline Intercept & 732 & 1556 & 3569 & 829 & 1679 & 3418 & & \\
Slope & -1.59 & -2.19 & -2.89 & -1.37 & -2.03 & -3.01 & $<0.001$ & 0.969 \\
$\mathrm{R}^{2}$ & 0.89 & 0.88 & 0.88 & 0.97 & 0.94 & 0.68 & & \\
\hline
\end{tabular}

${ }^{*} \mathrm{P}=$ probability for linear treatment effects. 
Table 4 In vitro methods and detection techniques used for estimating protein degradation

\begin{tabular}{|c|c|c|c|c|}
\hline Method & Degradation criteria & Analyte/method & Major problems & Reference \\
\hline Enzymes & Protein precipitation & $\mathrm{N}$ & $\begin{array}{l}\text { Fungal enzyme degradation } \\
\text { may differ from bacterial }\end{array}$ & $\begin{array}{l}\text { Krishnamoorthy et al. (1983) } \\
\text { Sniffen et al. (1992) }\end{array}$ \\
\hline \multicolumn{5}{|l|}{ Rumen fluid: } \\
\hline \multirow{2}{*}{ Conventional } & Protein precipitation & Gel electrophoresis & $\begin{array}{l}\text { Laborious, measures only loss } \\
\text { of intact proteins }\end{array}$ & $\begin{array}{l}\text { Nugent et al. (1983) } \\
\text { Messman and Weiss (1994) } \\
\text { Spencer et al. (1988) } \\
\text { McNabb et al. (1994) }\end{array}$ \\
\hline & End-product formation & Ammonia and gas & Laborious & Raab et al (1983) \\
\hline Inhibited & End-product formation & $\begin{array}{l}\text { Amino acids and } \\
\text { ammonia }\end{array}$ & Dying culture & Broderick (1987) \\
\hline Whole rumen contents & Protein precipitation & $\mathrm{N}$ & $\begin{array}{l}\text { Soluble proteins only } \\
\text { Limited no of vessels }\end{array}$ & This paper \\
\hline
\end{tabular}


Figure titles:

Figure 1 Exp. 1: Recovery of TCA-precipitable N (TCA-N) after in vitro incubation of casein at 2 and $39^{\circ} \mathrm{C}$.

Figure 2 Exp. 2 and 3: Recovery of TCA-precipitable N (TCA-N) from the first sampling time (1 min) after in vitro incubation at three different dosage levels of casein and egg protein with rumen contents $(\mathrm{RC})$ from either a dry or a lactating cow.

Figure 3 Exp. 2: Recovery of TCA-precipitable N (TCA-N) and NH3-N concentrations at different incubation times in vitro at three dosage levels of casein with rumen contents $(\mathrm{RC})$ from either a dry or a lactating cow.

Figure 4 Exp. 3: Recovery of TCA-precipitable N (TCA-N) and NH3-N concentrations at different incubation times in vitro at three dosage levels of egg protein with rumen contents (RC) from either a dry or a lactating cow.

Figure 5 Exp. 3: Disappearance of egg protein (mg TCA-N/kg rumen contents/min) versus dosage level (mg TCA-N/kg rumen contents) using rumen contents (RC) from either a dry or a lactating cow $(n=6)$ with estimates of Michaelis-Menten kinetic parameters ( $V_{\text {max }}=$ maximum rate; $K_{m}=a f f i n i t y$ constant). 


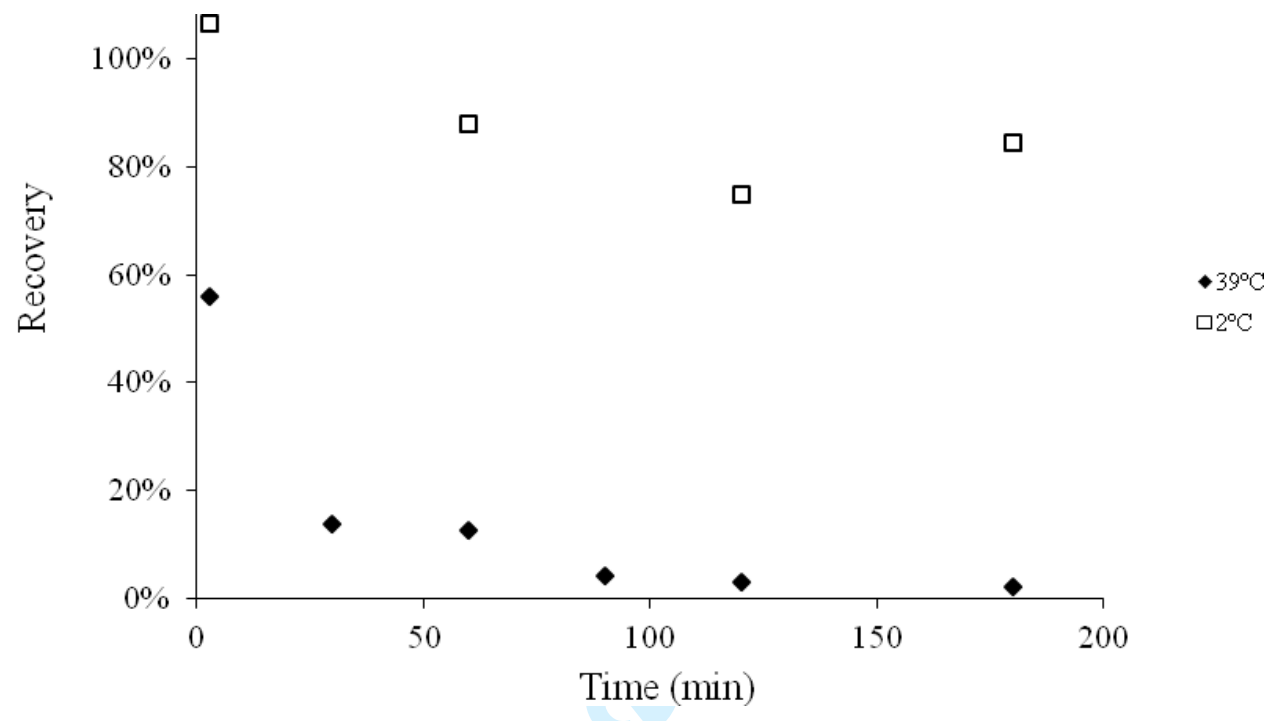

Fig. 1 

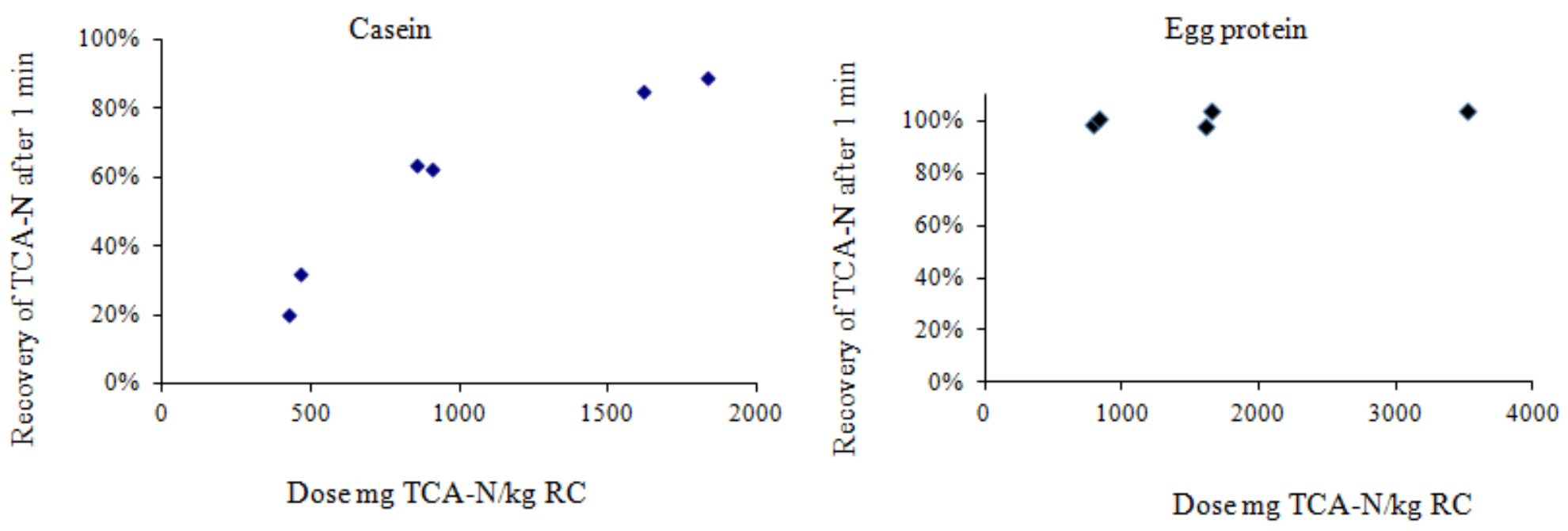

Fig. 2 
Dry cow

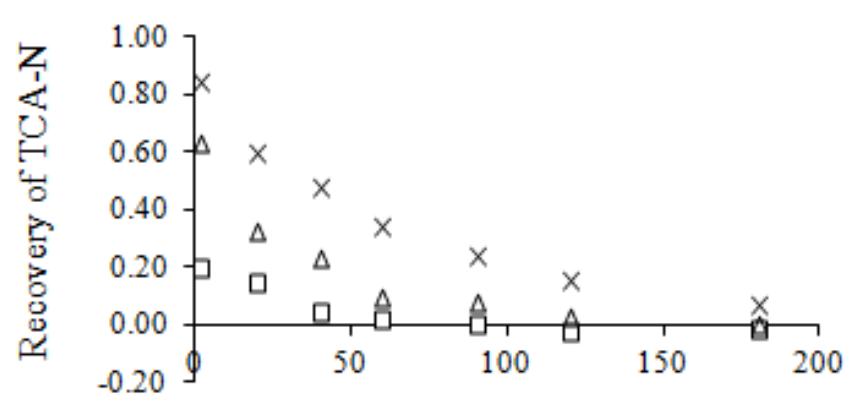

Time (min)

\section{Dry cow}

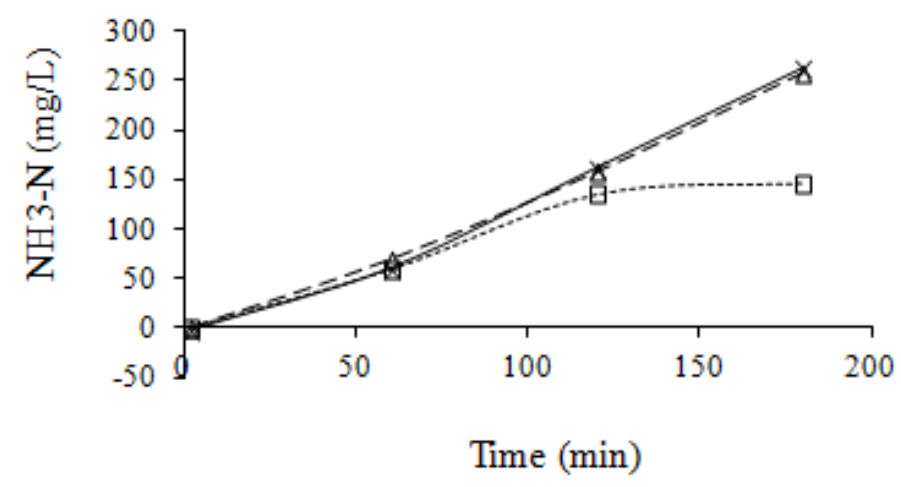

व3

$\Delta 6$

$\times 12$

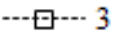

$-4-6$

$\leftarrow 12$

Fig. 3 


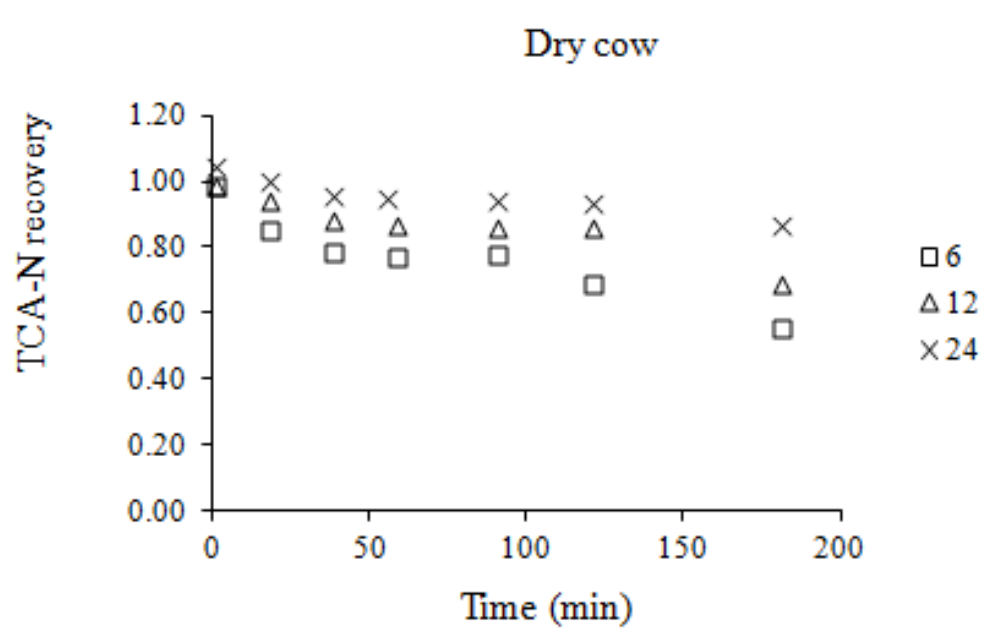

Dry cow

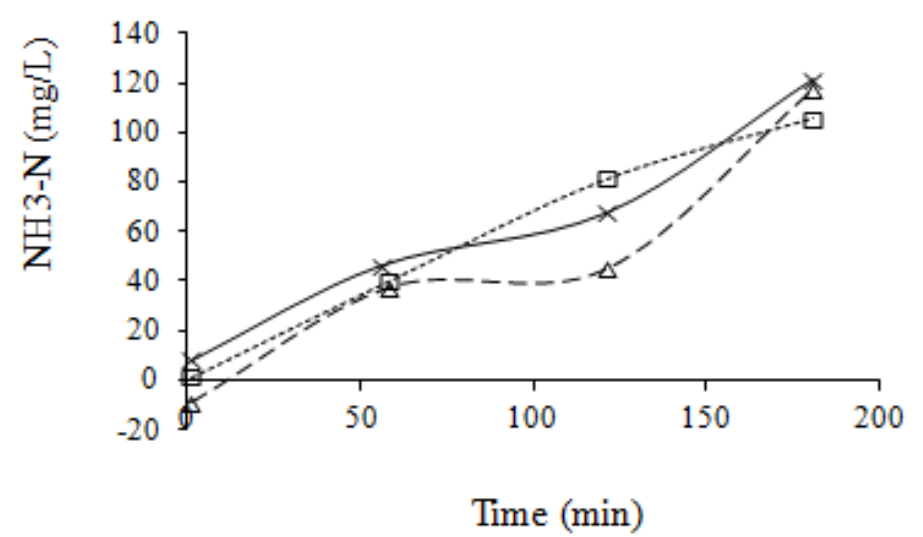

Lactating cow

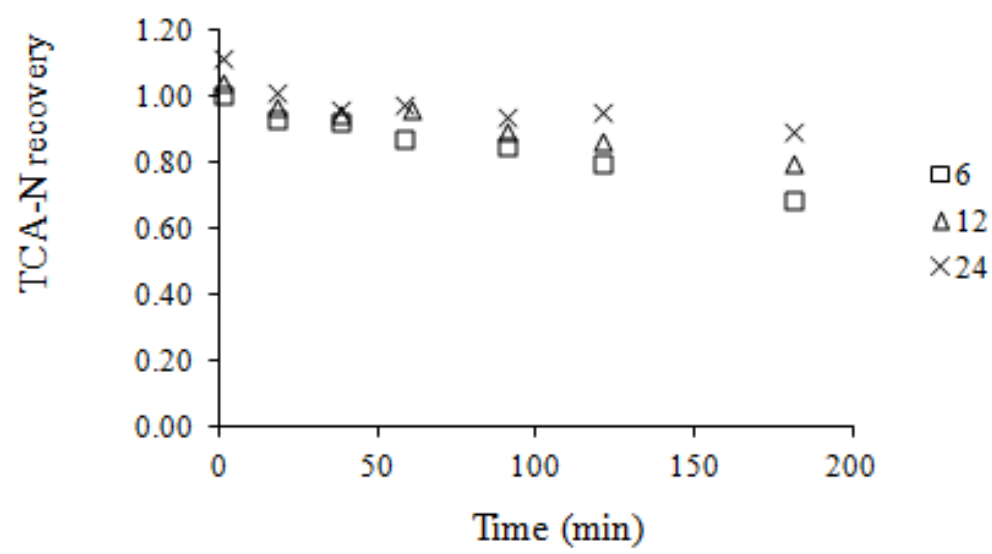

Lactating cow

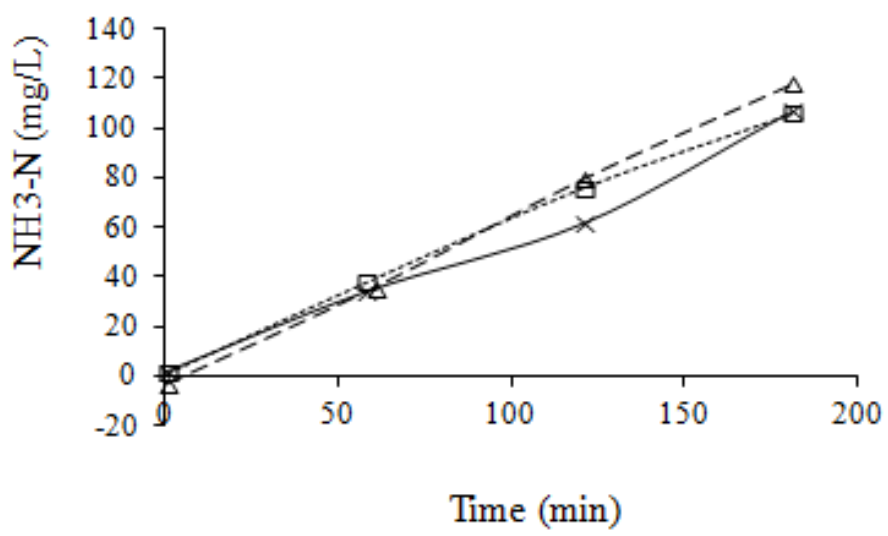

$\cdots \square-\cdots$

$-\triangle-\cdot 12$

$\times 24$

Fig. 4 


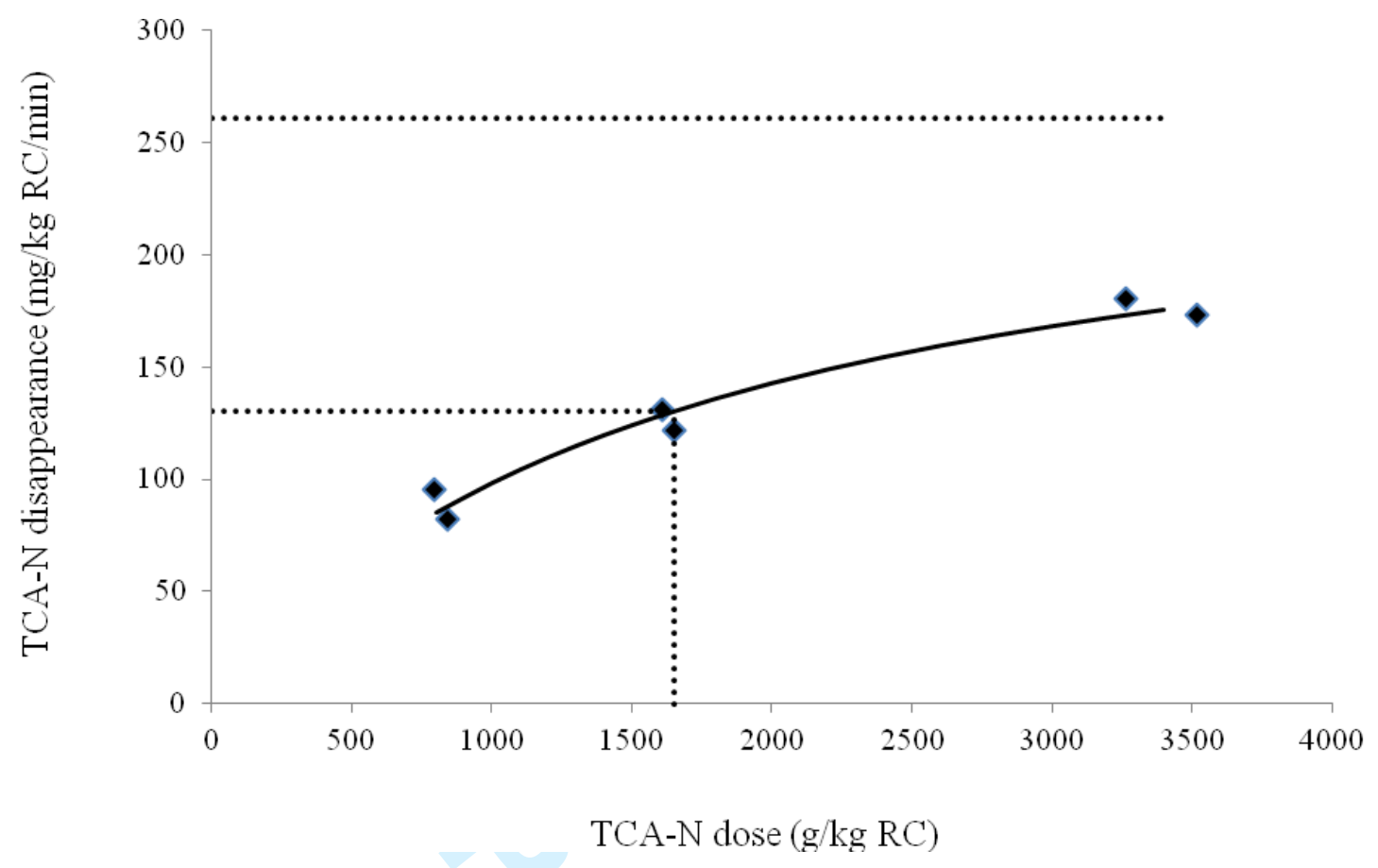

Fig. 5 